\title{
Development and validation of laboratory procedures for preimplantation diagnosis of Duchenne muscular dystrophy
}

\author{
Cathy Holding, David Bentley, Roland Roberts, Martin Bobrow, Christopher Mathew
}

\begin{abstract}
In order to develop and validate methods for the preimplantation diagnosis of Duchenne muscular dystrophy (DMD), we have established and evaluated PCR assays for the analysis of four loci within the DMD gene and for two $Y$ chromosome sequences in single cells. A model system using buccal cells picked from mouthwash samples has been used for an extensive evaluation of the sensitivity and specificity of the assays, and each assay has been tested in samples containing single cells, two cells, and three cells per tube. The four DMD and two $Y$ assays have been combined in duplex and triplex reactions to enable simultaneous diagnosis of DMD and of fetal sex. One of the DMD markers is a highly polymorphic simple tandem repeat locus which produces a basic DNA profile, and provides a control for contamination by foreign DNA. Amplification of DMD or $Y$ sequences was observed in 78 to $92 \%$ of single male cells, rising to $96 \%$ and $97 \%$ in tubes containing two or three male cells respectively. Coamplification of both a DMD and a $Y$ sequence together occurred with a mean success of $74 \%$ in single male cells, increasing to $93 \%$ with two, and $95 \%$ with three cells per tube. With appropriate precautions, we believe that it is now possible to proceed to clinical application of these procedures.

( $\mathcal{F}$ Med Genet 1993;30:903-9)
\end{abstract}

The sensitivity of the polymerase chain reaction method $(\mathrm{PCR})^{1}$ makes it possible to amplify specific DNA molecules from a single cell. This was first shown by $\mathrm{Li}$ et al, ${ }^{2}$ who analysed genetic markers from single sperm by probing PCR products with radiolabelled allele specific oligonucleotides in order to generate high resolution linkage maps. Another potential application of this technique is for the preimplantation diagnosis (PID) of genetic disease, by genetic analysis of a blastomere biopsy from an in vitro fertilised (IVF) preimplantation embryo. This strategy of embryo selection offers an important reproductive choice to families who find termination of pregnancy unacceptable, or who have already had several terminations of pregnancy after prenatal diagnosis of a genetic disorder. Handyside $e t a l$ showed that single blastomeres could be sexed by amplification of a Y specific sequence which is present at 500 to 8000 copies per cell. Nested PCR, a procedure using an outer pair of PCR primers for an initial series of cycles, and an inner pair for subsequent reamplification, provided the increased sensitivity and specificity necessary to detect and analyse single copy sequences in single cells. ${ }^{45}$

Early reports of the clinical application of these techniques have appeared based on removal of a single cell from eight cell stage embryos, ${ }^{67}$ or on the analysis of polar bodies. ${ }^{8}$ However, diagnostic errors have occurred in two of 10 pregnancies established after preimplantation diagnosis. A fetus diagnosed as female was subsequently found to be male by prenatal diagnosis and the pregnancy was terminated, ${ }^{910}$ and a fetus diagnosed by blastomere biopsy as unaffected with cystic fibrosis was shown by prenatal diagnosis to be affected. ${ }^{11}$

It is a tribute to the sensitivity of available techniques that single cell genetic diagnosis can even be considered, but if these procedures are to move into regular clinical practice, it is essential to establish the reliability with which single gene defects can be detected, and to design assays with adequate safeguards against technical error in diagnosis. ${ }^{1213}$ Diagnostic accuracy is improved if: (1) results always depend on the presence rather than the absence of a particular band; (2) more than one locus can be tested to reinforce the results; and (3) simultaneous checks can be run for contamination by foreign DNA.

We have developed such systems for the preimplantation diagnosis of Duchenne muscular dystrophy (DMD). The ethical and practical difficulties of testing large numbers of human blastomeres have led us to develop a model system for validation of PCR assays using single buccal epithelial cells. This has the advantage of relatively easy sample collection from persons of known genotypes.

In order to provide secure information on DMD genotype, fetal sex, and DNA contamination, it is necessary to test more than one locus simultaneously. We have evaluated PCR amplification of four different single copy sequences (pERT87-15, pERT87-8, exon 50, STR50) in the $\mathrm{X}$ linked DMD gene, which contain polymorphic DNA markers that are commonly used in carrier detection and prenatal diagnosis of DMD, or are markers for intragenic deletions which occur frequently in DMD patients. One or more of these sequences were amplified simultaneously with 
either a single copy or a repetitive copy $\mathrm{Y}$ chromosome sequence, which could be used to determine the sex of the embryo. We asked whether the $\mathrm{Y}$ repeat sequence reduced the efficiency of amplification of the single copy $\mathrm{X}$ sequences, and examined the relative efficiencies of the different $\mathrm{Y}$ specific reactions in diagnosing sex. We have assessed the use of $X$ markers together with Y specific PCRs, so that female sex is diagnosed by the positive presence of a specific paternally derived $\mathrm{X}$ marker, rather than by the absence of a Y marker, which is indistinguishable from amplification failure. We have evaluated coamplification of two single copy $\mathrm{X}$ sequences together, and in conjunction with the $\mathrm{Y}$ repeat sequence (that is, three simultaneous PCRs), to determine whether the amplification of the $X$ specific sequences could act as controls for each other and for the Y repeat PCR. We have tested a multiallelic CA repeat marker, STR50, ${ }^{14}$ which, in addition to being a highly informative diagnostic marker, provides a basic DNA profile and will be of value in detecting contamination.

We have determined the reproducibility of these assays performed on one, two, or three cells per tube, using buccal cells from donors of known genotype. Our results define the limits of reliable detection of single copy sequences for application to the preimplantation diagnosis of DMD and other monogenic defects for the techniques current in this laboratory. We confirm that preimplantation diagnosis can be sufficiently accurate for clinical application, provided that appropriate counselling and back up prenatal diagnosis are available. Whether it will be generally acceptable depends on the safety of embryo biopsy, which has yet to be extensively assessed, and on the acceptability of the IVF procedure to this group of patients.

Table $1 P C R$ primer sequences for DMD and $Y$ reactions.

\begin{tabular}{|c|c|c|}
\hline $\begin{array}{l}\text { pERT } 87-15 B \\
\text { Outer } \\
\text { primers: } \\
\text { Nested } \\
\text { primers: }\end{array}$ & $\begin{array}{l}8715 \mathrm{Ba} \\
8715 \mathrm{Bb} \\
8715 \mathrm{Bc} \\
8715 \mathrm{Bd}\end{array}$ & $\begin{array}{l}\text { 5'-CCTGCTTGTTGASGTCCCTAG-3' } \\
\text { 5'-GCTTAATTCTGAATAGTCACAAAAAG-3' } \\
\text { 5'-CTGATCAGGATCCAGTAACGAAAAGTGC-3' } \\
\text { 5'-CTAACACCTTCAAGATAAGAC-3' }\end{array}$ \\
\hline $\begin{array}{l}\text { PERT } 87-8 T \\
\text { Outer } \\
\text { primers: } \\
\text { Nested } \\
\text { primers: }\end{array}$ & $\begin{array}{l}878 \mathrm{Ta} \\
878 \mathrm{~Tb} \\
878 \mathrm{Tc} \\
878 \mathrm{Td}\end{array}$ & $\begin{array}{l}\text { 5'-CTAGAGTTTAGTCACATTAAG-3' } \\
\text { 5'-CCAATTAAAACCACAGCAGA-3' } \\
\text { 5'-GTCAGTTGGTCAGTAAAAGCC-3' } \\
\text { 5'-CAGGGTTCACAAGCTGTTCT-3' }\end{array}$ \\
\hline $\begin{array}{l}\text { Exon } 50 \\
\text { Outer } \\
\text { primers: } \\
\text { Nested } \\
\text { primers: }\end{array}$ & $\begin{array}{l}50 \mathrm{~F} \\
50 \mathrm{R} \\
50 \mathrm{~F} 1 \\
50 \mathrm{R} 1\end{array}$ & $\begin{array}{l}\text { 5'-CACCAAATGGATTAAGATGTTCATGAAT-3 } \\
\text { 5'-TCTCTCTCACCCAGTCATCACTTCATAG-3' } \\
\text { 5'-GGAAGTTAGAAGATCTGAGCTCTGAG-3' }^{\prime} \text { '-AGGCTCCAATAGTGGTCAGTCCAGG-3' }\end{array}$ \\
\hline $\begin{array}{l}\text { STR50 } \\
\text { Outer } \\
\text { primers: } \\
\text { Nested } \\
\text { primers: }\end{array}$ & $\begin{array}{l}\text { STR50F } \\
\text { STR50R } \\
\text { 150c } \\
\text { 150d }\end{array}$ & $\begin{array}{l}\text { 5'-AAGGTTCCTCCAGTAACAGATTTGG-3' } \\
\text { 5'-TATGCTACATAGTATGTCCTCAGAC-3' } \\
\text { 5'-CTGTCTCTCTGTCTGTCTCT-3' } \\
\text { 5'-CCAGAACCAGATGTATAACA-3' }\end{array}$ \\
\hline $\begin{array}{l}Y S 2 \\
\text { Outer } \\
\text { primers: } \\
\text { Nested } \\
\text { primers: } \\
\text { Y repeat }\end{array}$ & $\begin{array}{l}\text { YS2a } \\
\text { YS2b } \\
\text { YS2c } \\
\text { YS2d } \\
\text { YRa } \\
\text { YRb }\end{array}$ & $\begin{array}{l}\text { 5'-TGTATAGCAACGGAAAGCTC-3' } \\
\text { 5'-GTCTCTAAGTGGACATCTGT-3', } \\
\text { 5'-AGACATTGCTGTGGCAGTGT-3' } \\
\text { 5'-AATGTACCTGGGCCAACATC-3' } \\
\text { 5'-TGCCATTCGATCCATTCCATGCCA-3' } \\
\text { 5'-AATCATTGACTGGAAAGGCTGGGTG-3' }\end{array}$ \\
\hline
\end{tabular}

\section{Materials and methods}

PREPARATION OF CELLS

Male buccal cells were used in these evaluations. Amplifications of DMD and Y chromosome sequences are based, therefore, on DNA from a single chromosome. Buccal cells were obtained by gently scraping the inside of the cheek with a clean wooden applicator stick at least 30 minutes after consuming food or drink. The stick was gently twirled in a petri dish containing $5 \mathrm{ml}$ sterile phosphate buffered saline (PBS). Single cells, or groups of two or three cells, were removed from the petri dish using a finely drawn Pasteur pipette, and washed in a second petri dish also containing $5 \mathrm{ml}$ sterile PBS. Cells were removed using a second finely drawn Pasteur pipette into sterile $0.75 \mathrm{ml}$ tubes, containing $1 \mu \mathrm{l}$ sterile PBS. To each tube was added $1 \mu \mathrm{l}$ of $17 \mu \mathrm{mol} / 1 \mathrm{SDS}$ (sodium dodecylsulphate) and $2 \mu \mathrm{l}$ of $125 \mu \mathrm{g}$ / $\mathrm{ml}$ proteinase $\mathrm{K}$. The tubes were incubated at $37^{\circ} \mathrm{C}$ for 60 minutes, then $99^{\circ} \mathrm{C}$ for 15 minutes, centrifuged for 15 seconds in a microfuge, and then held at room temperature during preparation of reaction mixes for PCR.

AMPLIFICATION OF DMD AND Y LOCI BY PCR The four DMD loci amplified were as follows: pERT87-15B and pERT87-8T contain BamHI (B) or TaqI (T) restriction fragment length polymorphisms (RFLPs), are $47 \%$ and $41 \%$ heterozygous, respectively, ${ }^{15}$ and are deleted in $6.5 \%$ of all male DMD patients. STR50 is a CA repeat in intron 50 with a heterozygosity of $71 \cdot 6 \%,{ }^{14}$ and is thus of value as a marker for PCR contamination as well as for linkage analysis. STR50 is deleted in $10.6 \%$ of all DMD patients. ${ }^{16}$ Exon 50 , the most frequently deleted exon in the DMD gene, is deleted in $17.5 \%$ of all DMD patients. ${ }^{16}$

The YS2 sequence (amplified product $115 \mathrm{bp}$ ) is a single copy sequence located on the $\mathrm{Y}$ chromosome close to the pseudoautosomal boundary. ${ }^{17}$ The PCR assay for repetitive sequences on the $\mathrm{Y}$ chromosome (product size $170 \mathrm{bp}$ ) amplifies a region close to that described previously. ${ }^{6}$

PCR primers for the primary and nested amplification of these loci were designed from available sequences as follows. pERT87-15B and $p E R T 87-8 T$ : Koenig et al, ${ }^{18}$ Roberts et $a l,{ }^{19}$ Beggs et $a l,{ }^{20}$ and from sequence data derived by $R$ Roberts (GenBank accession numbers L05531 and L05532). STR50: Clemens et $a l,{ }^{14}$ and from sequence data derived by R Flomen. YS2: Ellis $e t a l^{17}$ and $\mathrm{N}$ Ellis (personal communication). Y repeat: Nakahori et al. ${ }^{21}$

The primer sequences for the six loci are listed in table 1 . All primer pairs were tested on genomic DNA from persons of known genotype before use in single cell amplifications.

$\mathrm{PCR}^{1}$ was carried out in $50 \mu \mathrm{l}$ reaction mixes using Cetus GeneAmp kit components as directed by the manufacturer. Alternatively, reactions were carried out in other commercially available buffers with final concentrations of 
$1.5 \mathrm{mmol} / 1 \mathrm{MgCl}_{2}, 200 \mu \mathrm{mol} / 1$ deoxynucleotide triphosphates (dNTPs), $1 \mu \mathrm{mol} / 1$ of each PCR primer, and $0.05 \%$ of Nonidet P-40 (NP40). A master mix of these reagents was prepared sufficient for each experiment, according to the Cetus instructions, except for the addition of $2.5 \mu \mathrm{l}$ of $1 \% \mathrm{NP} 40$ and 1.25 units of Taq DNA polymerase for each reaction mix.

A total of $45 \mu$ l reaction mix containing a mixture of outer primers was added to each tube containing the lysed cells, by pipetting the liquid down the side of the tube from the top. No other mixing was carried out. One drop of mineral oil (Sigma light white in $6 \mathrm{ml}$ dropper bottles) was overlaid on each reaction mix and the tubes placed in a thermal cycler. Cycle conditions were set at $93^{\circ} \mathrm{C}$ for one minute, $58^{\circ} \mathrm{C}$ for one minute, $72^{\circ} \mathrm{C}$ for three minutes for 30 cycles, followed by extension at $72^{\circ} \mathrm{C}$ for five minutes. An annealing temperature of $40^{\circ} \mathrm{C}$ in place of $58^{\circ} \mathrm{C}$ was used for the multiplex amplification of pERT 87-15B, YS2, and STR50.

Following 30 cycles of amplification, tubes were held at room temperature, usually overnight. Reaction mixes were separated from oil into sterile lidded microtitre dishes. Reamplification reaction mixes were prepared and dispensed on ice, overlaid with mineral oil, and then $1 \mu \mathrm{l}$ of the first amplification mix was added to separate second reaction mixes containing inner primer pairs for each locus, and mixed by gently flicking the tubes. Tubes were reamplified for 30 cycles exactly as previously described, except for STR50, which was reamplified as follows: $93^{\circ} \mathrm{C}$ for one minute, $55^{\circ} \mathrm{C}$ for one minute, $72^{\circ} \mathrm{C}$ for three minutes for 20 cycles only.

\section{ANALYSIS OF PCR PRODUCTS}

\section{$p E R T 87-15 B$ and $p E R T 87-8 T$}

Second round amplification products $(10 \mu \mathrm{l})$ were digested with $10 \mathrm{U}$ of BamHI or TaqI respectively in a final volume of $30 \mu \mathrm{l}$ at $37^{\circ} \mathrm{C}$ for two to four hours in buffers supplied by the manufacturers. Digestion products were electrophoresed at $60 \mathrm{~mA}$ for 20 minutes in $4 \%$ NuSieve agarose gels containing ethidium bromide and visualised under ultraviolet light.

\section{STR50 and exon 50}

PCR product and alleles could be visualised in NuSieve gels containing ethidium bromide. In order to obtain optimal resolution of all of the STR50 alleles, the PCR products were radioactively labelled and electrophoresed in a sequencing gel as follows. During the second round of amplification, one internal primer was end labelled using $\left[\gamma-{ }^{32} \mathrm{P}\right]$ ATP. ${ }^{22}$ PCR was carried out using 1 pmol of the labelled primer and $10 \mathrm{pmol}$ of the second, unlabelled internal primer per reaction mix. Products were electrophoresed in 5\% denaturing acrylamide gels at $40 \mathrm{~W}$ for 1.5 hours, fixed, washed, dried, and autoradiographed. Alleles were scored after one to five hours.
YS2 and Y-repeat

Products from the second (YS2) or first ( $Y$ repeat) PCR were separated from oil, and 10 to $15 \mu \mathrm{l}$ electrophoresed in $4 \%$ NuSieve gels as for pERT87-15B and pERT87-8T.

\section{CONTROLS FOR PCR CONTAMINATION}

The degree of contamination in the cell collection and PCR procedures was assessed as follows. (1) The cell collection procedure was mimicked, using only PBS in the absence of cells; and (2) PCR reactions were dispensed and subjected to amplification without any other manipulations. Control tubes which contained only reaction mix were included in each experiment.

\section{PRECAUTIONS AGAINST CONTAMINATION}

The set up area for preparation of the tubes containing the cells was in a separate laboratory from that used for PCR. Cells were handled and reaction mixes prepared in a class II laminar flow hood. Autoclaved plugged tips were used for aliquotting the $1 \mu \mathrm{l}$ PBS into sterile tubes, for preparation of master mixes, and for aliquotting the reaction mixes into tubes. Full sterile handling precautions were observed. PCR was performed and PCR products were separated from oil in the main laboratory. Amplified samples were never taken into the set up laboratory. A separate set of automatic micropipettes was used for reamplification, and these were taken apart and UV irradiated for 15 to 20 minutes before use in each experiment. Sterile unplugged tips were used, but these were purchased preracked. Tips were used once only and discarded. A wet tip was never placed in the master mix. After reamplification, reaction mixes were separated from oil using a third set of untreated micropipettes and laboratory stock pipette tips.

\section{Results}

Examples of the electrophoretic analysis of the products of coamplification of DMD and Y sequences are shown in fig 1 . Nested amplification of single copy DMD and $\mathrm{Y}$ sequences produced a single clear band of the expected size from most tubes which contained one or two male buccal cells. The repetitive $\mathrm{Y}$ sequence, which was analysed after only a single round of amplification, showed the expected PCR product and a band resulting from primer-dimer formation (fig $1 C$ and $D$, and Handyside $e t a l^{6}$ ). In addition, the results in fig 1 show that failure of amplification of a single copy sequence can occur independently of amplification of a second sequence in the same cell. For example, in fig 1A (track 6) the pERT87-15B locus amplified successfully, whereas no signal was obtained from the YS2 locus. This cell would therefore be typed incorrectly as female in origin. In fig $1 \mathrm{~B}$ (track 5 ) it is the $87-15 \mathrm{~B}$ reaction that has failed, whereas the YS2 locus has been amplified.

The results of coamplification of DMD 
A One cell per tube pERT 87-15B

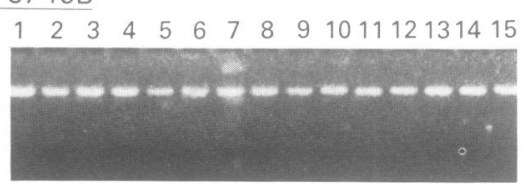

YS2

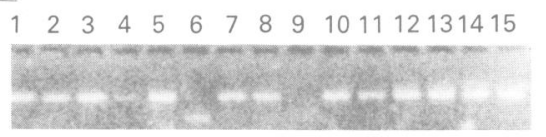

C One cell per tube

pERT 87-15B

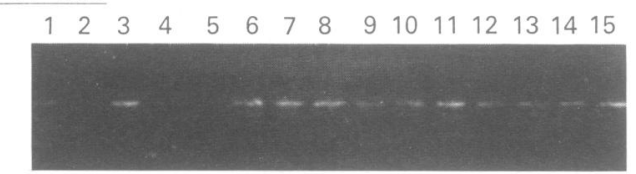

$\underline{Y R}$

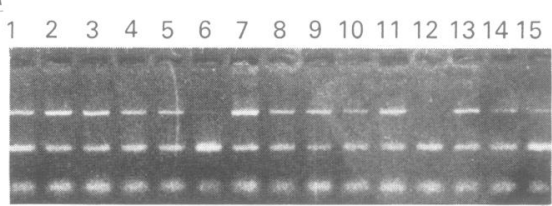

$Y$ specific band

Primer-dimer

Primers

B Two cells per tube pERT 87-15B

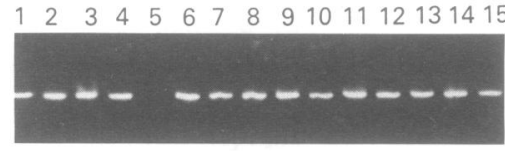

YS2

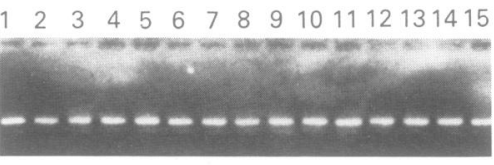

D Two cells per tube pERT 87-15B

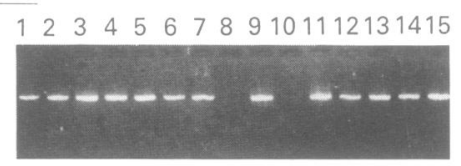

YR

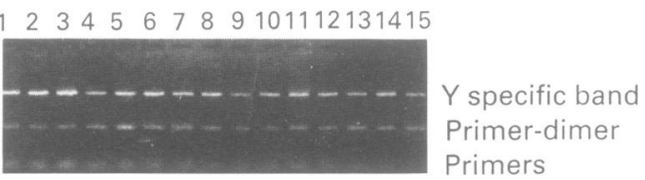

Figure 1 Examples of coamplification of the pERT87-15B region with $Y S 2$ and with $Y R$. (A) pERT87-15B with YS2 in single cells. (B) $p E R T 87-15 B$ with $Y S 2$ in two cells per tube. (C) pERT87-15B with YR in single cells. (D) $p E R T 87-15 B$ with $Y R$ in two cells per tube.

Table 2 Results of duplex amplification of single copy $X$ sequences with single or multiple copy $Y$ sequences in male buccal cells.*

\begin{tabular}{lrrrrrrrrrrrrrrrrr}
\hline & \multicolumn{3}{c}{ X and $\mathrm{Y}$} & \multicolumn{3}{c}{ X only } & \multicolumn{3}{c}{ Y only } & & \multicolumn{3}{c}{ Neither } & \multicolumn{3}{c}{$\begin{array}{c}\text { No of samples } \\
\text { assayed }\end{array}$} \\
\hline Cells/tube & 1 & 2 & 3 & 1 & 2 & 3 & 1 & 2 & 3 & 1 & 2 & 3 & 1 & 2 & 3 \\
\hline pERT87-15B/YS2 & 74 & 90 & 93 & 13 & 2 & 5 & 7 & 8 & 2 & 6 & 0 & 0 & 94 & 48 & 64 \\
pERT87-15B/YR & 74 & 91 & 90 & 0 & 1 & 0 & 19 & 7 & 4 & 7 & 1 & 6 & 80 & 80 & 40 \\
pERT87/8T/YS2 & 72 & 97 & 97 & 7 & 0 & 0 & 2 & 0 & 2 & 19 & 3 & 1 & 40 & 40 & 40 \\
pERT87-8T/YR & 75 & 95 & 100 & 2 & 0 & 0 & 15 & 5 & 0 & 8 & 0 & 0 & 80 & 40 & 40 \\
\hline
\end{tabular}

Individual amplification efficiencies of the four reactions.*

\begin{tabular}{lccc}
\hline Cells/tube & 1 & 2 & 3 \\
\hline pERT87-15B & 81 & 92 & 94 \\
pERT87-8T & 78 & 96 & 98 \\
YS2 & 79 & 98 & 97 \\
YR & 92 & 98 & 98 \\
\hline
\end{tabular}

* Results are expressed as the percentage of tubes which gave an amplification product.

RFLPs with Y chromosome sequences in one, two, or three male cells per tube are shown in table 2 , based on 686 individual amplification experiments. Successful amplification of both a diagnostic marker for $\mathrm{DMD}$ and a $\mathrm{Y}$ sequence for fetal sexing occurred at a rate of $74 \%$ for single cells, rising to $93 \%$ and $95 \%$ for two and three cells respectively. The success rates for the two DMD markers were equivalent whether they were coamplified with a single copy $\mathrm{Y}$ sequence or with the $\mathrm{Y}$ repeat. The individual amplification efficiencies for the three single copy sequences within the duplex reactions (table 2) were very similar, with a range of $78 \%$ to $81 \%$ in single cells, and approached $100 \%$ when two or three cells were used in each reaction. The $\mathrm{Y}$ repeat reaction was significantly more robust than the single copy reactions at the single cell level $(92 \% v$
$79 \%$ ), but had a similar efficiency in samples which contained two or three cells. The data from table 2 can be used to estimate the proportion of male single cells in which fetal sex would be incorrectly diagnosed as female. A total of 20/134 male single cells were positive for the $\mathrm{X}$ reaction and negative for the single copy $\mathrm{Y}$ reaction (YS2), giving an error rate of $14.9 \%$. This fell to $2 / 160$ cells, or $1.3 \%$, with the $\mathrm{Y}$ repeat. The rate of misdiagnosis of sex in samples containing two or three cells was less than $1 \%$ for the $Y$ repeat, but $2 \cdot 3 \%$ and $4.8 \%$ for the single copy $\mathrm{Y}$ reaction.

Amplification efficiency was also examined in two different triplex PCR amplifications. In the first triplex, exon 50, which is one of the exons which is most frequently deleted in the dystrophin gene, ${ }^{15}$ was added to the pERT87$15 B$ and $Y R$ reactions. The data in table 3 shows that coamplification of this third locus does not have a significantly adverse effect on the $Y R$ reaction, although the efficiency of the pERT87-15B reaction is somewhat lower.

Simultaneous amplification of all three loci occurred at a relatively low rate in single cells, but at high rates with two or three cells. The efficiency of amplification of the highly polymorphic CA repeat marker within intron 50 of the DMD gene (STR50 ${ }^{14}$ ) was also examined both as a single marker and in a triplex reaction with pERT87-15B and YS2 (table 4). The 
Table 3 Results of triplex amplification (exon 50 , pERT87-15B, and YR) in male buccal cells.*

\begin{tabular}{lccc}
\hline & $\begin{array}{c}1 \text { cell/tube } \\
(\mathrm{n}=58)\end{array}$ & $\begin{array}{c}2 \text { cells/tube } \\
(\mathrm{n}=40)\end{array}$ & $\begin{array}{c}3 \text { cells/tube } \\
(\mathrm{n}=38)\end{array}$ \\
\hline All 3 alleles amplified & 46 & 91 & 100 \\
2 out of 3 amplified & 23 & 7 & 0 \\
1 out of 3 amplified & 23 & 2 & 0 \\
None amplified & 8 & 0 & 0 \\
\hline
\end{tabular}

Amplification efficiency

\begin{tabular}{lrrr}
\hline pERT87-15B & 67 & 97 & 100 \\
Exon 50 & 50 & 90 & 100 \\
YR & 89 & 100 & 100 \\
\hline
\end{tabular}

* Results expressed as percentage of tubes giving a reaction. $\mathrm{n}=$ number of tubes tested.

Table 4 Results of amplification of the $C A$ repeat marker (STR50) in male buccal cells.

\begin{tabular}{|c|c|}
\hline $\begin{array}{l}\text { A STR50 alone } \\
1 \text { cell/tube }(\mathrm{n}=70) \\
2 \text { cells/tube }(\mathrm{n}=39) \\
B \text { Triplex }(S T R 50, p E R T \\
\text { cells }(n=50)\end{array}$ & $\begin{array}{l}67 \% \\
97 \% \\
87-15 B \text {, and YS2) in single male }\end{array}$ \\
\hline $\begin{array}{l}\text { All three alleles } \\
\text { amplified } \\
2 \text { out of } 3 \text { amplified } \\
1 \text { out of } 3 \text { amplified } \\
\text { None amplified }\end{array}$ & $\begin{array}{c}56 \% \\
20 \% \\
8 \% \\
16 \%\end{array}$ \\
\hline $\begin{array}{l}\text { Amplification efficiencies } \\
\text { STR50 } \\
\text { pERT87-15B } \\
\text { YS2 }\end{array}$ & $\begin{array}{l}74 \% \\
72 \% \\
70 \%\end{array}$ \\
\hline
\end{tabular}

results indicate that STR50 is not affected by the presence of the other two loci, and can be amplified with an efficiency similar to conventional single copy loci. The value of this marker in detecting contaminating DNA is shown in fig 2 .

The results of experiments to test for contamination of the PCR are shown in table 5. Mimicking of the cell collection procedure with PBS produced one false positive in 188 PCRs $(0.5 \%)$. No false positives were detected in 214 PCRs from reaction blanks.

\section{Discussion}

This study shows that PCR of single copy loci in the DMD gene and from the Y chromosome in a large series of single buccal cells does not consistently produce successful amplification in more than about 70 to $80 \%$ of tests. Our results are in agreement with those of Monk et $a l,{ }^{23}$ who detected both alleles of the $\beta$ globin gene with an efficiency of $71 \%$ in single buccal cells, and Verlinsky et al ${ }^{11}$ who obtained success rates of $78 \%$ and $83 \%$ in polar bodies and blastomeres respectively. Amplification efficiencies of $95 \%$ or greater have been reported for the cystic fibrosis locus in single spermato$\mathrm{zoa},{ }^{24}$ and for the $\mathrm{G} \gamma$ globin and parathyroid hormone gene loci, also in spermatozoa. ${ }^{25}$ It is possible that amplification success rates may be tissue or locus specific, perhaps because of differences in chromatin structure, with the limiting factor for PCR being the removal of all chromosomal proteins from the target sequence. Preliminary results from a limited number of single human blastomeres (C Holding and $S$ Pickering, unpublished data) showed that the pERT87-15B locus was amplified in 23 of 26 male cells, but a larger series will be required to establish whether success rates in blastomeres are significantly different from buccal cells. In contrast to the results for single copy sequences, amplification of the $\mathrm{Y}$ repeat from single cells produced success rates in excess of $90 \%$ after a single round of PCR.

Amplification from two cells increased our success rates to about $93 \%$, and with three cells to about $95 \%$. The use of two cells per assay rather than a single cell would therefore markedly improve the efficiency of the diagnosis. There is evidence that two cell biopsies in mice $^{26}$ and in humans ${ }^{10}$ are compatible with continued short term in vitro development of an early embryo. A judgement will have to be made between the greater diagnostic accuracy of using larger biopsies and any increased hazard to the embryo.

Analysis of the failure rates of individual reactions within duplex and triplex assays does not suggest a significant degree of interference of one assay with another (tables 2, 3, and 4). This will be particularly helpful in the context of preimplantation diagnosis for $\mathrm{DMD}$, since it allows for the diagnosis of fetal sex as well as for typing more than one marker in the DMD gene, which has a high frequency of intragenic recombination..$^{27}$ The fact that coamplification of the $\mathrm{Y}$ repeat sequence does not affect amplification of single copy DMD loci is also encouraging, given the greater sensitivity of this assay for the diagnosis of fetal sex. However, the probability of detection of all of the alleles from two or more loci in single cells is relatively low. The coamplification rates are approximately equal to the products of the success rates of individual reactions, reinforcing the conclusion that the different amplification reactions proceed more or less independently.

Product from one locus does not guarantee product from any of the other loci present in the same cell: the Y specific reaction, whether it was from the single or multiple copy sequence, failed on occasion in single cells, for example in fig 2A (lanes 6 and 9), even though the $\mathrm{X}$ specific reaction succeeded and vice versa. This also occurred when three sequences were amplified simultaneously (tables 3 and 4). Since each reaction at the single cell level appears to be proceeding independently of any others in the same tube, internal PCR controls are not reliable indicators of amplification of the test sequence at this level of sensitivity.

The data from tables 2,3 , and 4 can be used to assess success rates and error rates for the diagnosis of fetal sex and of DMD. Of particular concern would be the misdiagnosis of a male embryo as female as a result of failure of amplification of the $\mathrm{Y}$ sequence. The greater sensitivity of the $\mathrm{Y}$ repeat reaction, and the fact that it does not interfere significantly with the $X$ reactions, suggests that it should be used in preference to single copy $Y$ sequences for sexing blastomeres. The error rate for the $\mathrm{Y}$ repeat in single cells (that is, male cells with a $\mathrm{X}^{+} \mathrm{Y}^{-}$genotype) is 1 to $2 \%$, which falls to less than $1 \%$ for two or three cells. The consequences of a false positive result from the $\mathrm{Y}$ reaction are less significant and are likely to be 


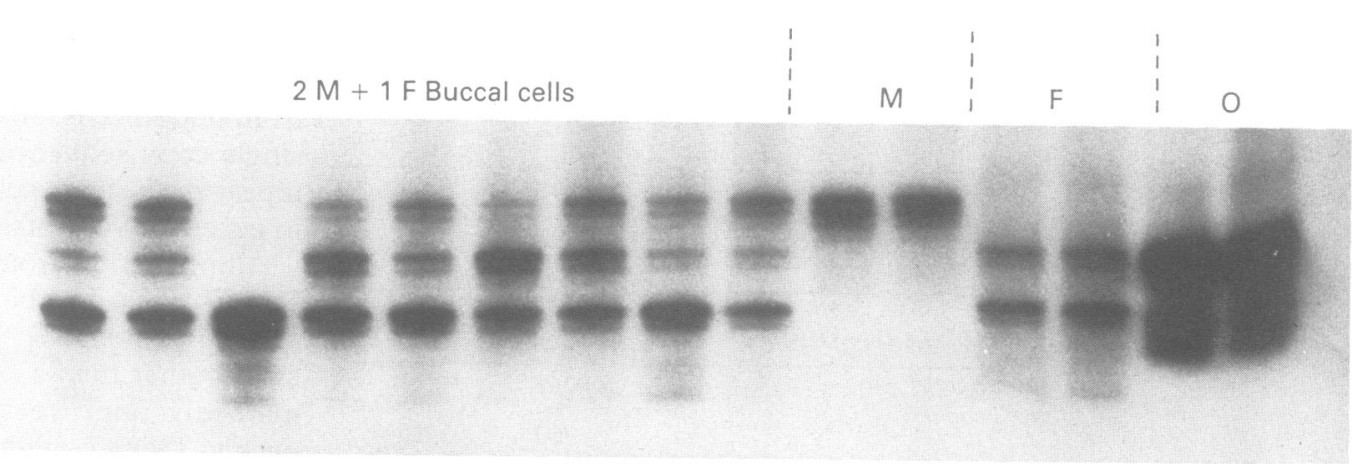

Figure 2 Amplification of CA repeats in intron 50 (STR50). Detection of contamination of samples containing two male buccal cells with one female buccal cell, with a different number of $C A$ repeats. Track 3 shows amplification of one allele of contaminating DNA in the absence of amplification of the sample DNA.M=male pattern; $F=$ female pattern; $\mathrm{O}=$ operator $(\mathrm{CH})$ pattern.

Table 5402 contamination controls pooled from all experiments.

\begin{tabular}{|c|c|c|c|c|c|c|}
\hline Type of blank & $\begin{array}{c}\text { Total No of } \\
\text { blanks assayed }\end{array}$ & pERT87-15B & YS2 & YR & pERT87-8T & No of expts \\
\hline Cell free PBS & $\begin{array}{l}94 \\
47 \\
47\end{array}$ & 1 & 0 & 0 & & $\begin{array}{l}2 \\
1 \\
1\end{array}$ \\
\hline Reaction mix only & $\begin{array}{l}77 \\
70 \\
37 \\
30\end{array}$ & 0 & 0 & 0 & 0 & $\begin{array}{l}8 \\
6 \\
8 \\
6\end{array}$ \\
\hline
\end{tabular}

Results expressed as percentage of tubes positive for PCR product.

rare provided that adequate safeguards against contamination are applied. In the absence of significant contamination, half of the embryos from an IVF procedure could therefore be diagnosed as female, and hence unaffected, with a high degree of accuracy. In male embryos, both the $\mathrm{X}$ and $\mathrm{Y}$ loci will be amplified in about $75 \%$ of single cells (table 2 ). Since half of the male embryos, on average, from a DMD carrier will be affected, $37.5 \%$ of male embryos could be typed as unaffected if diagnosis was based on biopsy of a single cell. Thus for every 10 embryos, an average of six or seven would be diagnosed as unaffected. This figure rises to an average of seven or eight if two cells are used for the analysis, and the accuracy of the diagnosis of fetal sex would be significantly increased.

This assessment of diagnostic accuracy is based on the assumption that contamination of the blastomere biopsy with spermatozoa, cumulus cells, or cells from the operator can be prevented or detected, and that the PCR reactions do not become contaminated with amplification products from other sources. Provided rigorous protocols, designed to avoid contamination of the reactions with spurious PCR products or operator cells, are followed (see Materials and methods), false positives from these sources occur at a very low frequency (table 5). Contamination of the blastomere biopsy with paternal or maternal cells could be detected by analysis with highly polymorphic microsatellite markers. If both parents, and the laboratory personnel involved, are genotyped beforehand with several such markers from the DMD gene, ${ }^{14}$ a marker could generally be found which allowed the two maternal alleles and the paternal allele to be distinguished. We have shown this with a single $\mathrm{X}$ chromosome simple tandem repeat locus (fig 2). However, table 4 indicates that the amplification efficiency of STR50 is only $74 \%$ when amplified in conjunction with pERT87-15B and YS2, and so, in theory, a single contaminating cell in the embryo biopsy could only be identified three out of four times. In two cells, as with conventional loci, its amplification efficiency is very high.

In conclusion, our results suggest that two blastomeres from a single embryo biopsy would be necessary and sufficient for reliable preimplantation genetic diagnosis. Diagnosis could be achieved by testing a single blastomere, but the rate of technical failures and of misdiagnosis would be significantly higher. In general, these results give an encouraging view of the potential for accurate preimplantation diagnosis of monogenic disorders, but we believe that the following principles should be adhered to. (1) No diagnosis should be based on the absence of a result, but always on the presence of an amplified sequence. (2) Wherever possible, more than one diagnostic test should be applied simultaneously, as a cover for error or failure of one of the reactions. (3) Rigorous tests for DNA contamination should be included with all samples, and wherever possible included in the specific diagnostic assay itself. (4) All patients should be properly counselled beforehand, and confirmatory prenatal diagnosis undertaken later in pregnancy. (5) All continuing pregnancies should be followed up for some years after birth, to confirm the safety of the biopsy procedures.

We thank Rachel Flomen for the provision of STR50 sequence data, and Elizabeth Manners for her assistance in the preparation of the manuscript. This work was supported by The Wellcome Trust, The Generation Trust, The Muscular Dystrophy Group of Great Britain and Northern Ireland, and The Spastics Society. 
1 Saiki RK, Gelfand DH, Stoffel S, et al. Primer-directed enzymatic amplification of DNA with a thermostable DNA polymerase. Science 1988;239:487-91.

2 Li H, Cui X, Arnheim N. Direct electrophoretic detection of the allelic state of single DNA molecules in human sperm by using the polymerase chain reaction. Proc Nat Acad Sci USA 1988;87:4580-4.

3 Handyside AH, Pattinson JK, Penketh RJA, Delhanty JDA, Winston RML, Tuddenham EGD. Biopsy of human preimplantation embryos and sexing by DNA amplification. Lancet 1989;i:347-9.

4 Holding C, Monk M. Diagnosis of $\beta$-thalassaemia by DNA amplification in single blastomeres from mouse preimplantation embryos. Lancet 1989;ii:532-5.

5 Monk M, Holding C. Amplification of a beta-haemoglobin sequence in individual hum

6 Handyside AH, Kontogianni EH, Hardy K, Winston RML. Pregnancies from biopsied human preimplantation embryos sexed by Y-specific DNA amplification. Nature embryos sexed by

7 Handyside AH, Lesko JG, Tarin JJ, Winston RML, Hughes MR. Birth of a normal girl after in vitro fertilisation and preimplantation diagnostic testing for cystic fibrosis. N Engl f Med 1992;327:905-9.

8 Verlinsky Y, Ginsberg N, Lifchez A, Valle J, Moise J, Strom C. Analysis of the first polar body: preconception genetic diagnosis. Hum Reprod 1990;50:826-9.

9 Soussis I, Jeer HS, Packham C, Margara RA, Handyside AH, Winston RML. Ultrasonic and biochemical parameters of early pregnancies following transfer of biopsied human embryos for $\mathrm{X}$-linked genetic disorders. Hum Reprod 1991;6(suppl 1):138.

10 Hardy K, Handyside AH. Biopsy of cleavage stage human embryos and diagnosis of single gene defects by DNA embryos and diagnosis of single gene defects by DNA

11 Verlinsky Y, Rechitsky S, Cieslak J, et al. Reliability of preconception and preimplantation genetic diagnosis. $A m$ f Hum Genet 1991;49(suppl):22.

12 Navidi W, Arnheim N. Using PCR in preimplantation genetic disease diagnosis. Hum Reprod 1991;6:836-49.

13 Trounson AL. Preimplantation genetic diagnosis: counting chickens before they hatch? Hum Reprod 1992;7:583-4.

14 Clemens PR, Fenwick RG, Chamberlain JS, et al. Carrier detection and prenatal diagnosis in Duchenne and Becker muscular dystrophy families using dinucleotide repeat polymorphisms. Am f Hum Genet 1991;49:951-60.
15 Kunkel LM, Hejtmancik JF, Caskey CT, et al. Analysis of deletions in DNA from patients with Becker and Duchenne muscular dystrophy. Nature 1986;322:73-7.

16 Abbs S. Molecular and genetic analysis of the Duchenne muscular dystrophy gene with application for counselling and carrier diagnosis. PhD Thesis, University of London,

17 Ellis N, Taylor A, Bengtsson BO, Kidd J, Rogers J, Goodfellow P. Population structure of the human pseudoautosomal boundary. Nature 1990;344:663-5.

18 Koenig M, Monaco AP, Kunkel LM. The complete sequence of dystrophin predicts a rod-shaped cytoskeletal protein. Cell 1988;53:219-28.

19 Roberts RG, Cole CG, Hart KA, Bobrow M, Bentley DR Rapid carrier and prenatal diagnosis of Duchenne and Becker muscular dystrophy. Nucleic Acids Res Becker musc

20 Beggs AH, Koenig M, Boyce FM, Kunkel LM. Detection of $98 \%$ of DMD/BMD gene deletions by polymerase chain reaction. Hum Genet 1990;86:45-8.

21 Nakahori Y, Mitani K, Yamada M, Nakagome Y. A human Y-chromosome specific repeated DNA family (DYZ1) consists of a tandem array of pentanucleotides. Nucleic Acids Res 1986;14:7569-80.

22 Sambrook J, Fritsch EF, Maniatis T. Molecular cloning: a laboratory manual. 2nd ed. Cold Spring Harbor: Cold Spring Harbor Laboratory Press, 1989.

23 Mring Hath the normal and mutant alleles in single cells of individuals heterozygous for the sickle cell mutation-prelude to preimplantation diagnosis. Prenat Diagn 1993;13:45-53.

24 Liu J, Lissens W, Devroey P, van Steirteghem A, Liebaers I. Efficiency and accuracy of polymerase-chain-reaction assay for cystic fibrosis allele $\triangle \mathrm{F} 508$ in single cell. Lance 1992;339:1190-2.

25 Cui X, Li H, Goradia T, et al. Single sperm typing: determination of genetic distance between the ${ }^{G} \gamma$-globin and parathyroid hormone loci by using the polymerase chain reaction and allele-specific oligomers. Proc Natl chain reaction and allele-specific

26 Liebaers I, Sermon K, Lissens W, et al. Preimplantation diagnosis. Hum Reprod 1992;7:107-10.

27 Abbs S, Roberts RG, Mathew CG, Bentley DR, Bobrow $M$. Accurate assessment of intragenic recombination frequency within the Duchenne muscular dystrophy gene. Genomics 1990;7:602-6. 